\title{
Service Quality and Customer Satisfaction: A Case Study of Hotel Industry in Vietnam
}

\author{
Nguyen Hue Minh ${ }^{1,2}$, Nguyen Thu Ha ${ }^{1}$, Phan Chi Anh ${ }^{1} \&$ Yoshiki Matsui ${ }^{2}$ \\ ${ }^{1}$ Faculty of Business Administration, University of Economics and Business, Vietnam National University, \\ Vietnam \\ ${ }^{2}$ College of Business Administration, Yokohama National University, Japan \\ Correspondence: Nguyen Hue Minh, Faculty of Business Administration, University of Economics and Business, \\ Vietnam National University, Vietnam; College of Business Administration, Yokohama National University, \\ Japan. Tel: 81-80-3591-8590. E-mail: nguyenhueminh146@gmail.com; nguyen-minh-zk@ynu.jp
}

Received: July 19, 2014 Accepted: January 1,2015 Online Published: April 20, 2015

doi:10.5539/ass.v11n10p73 URL: http://dx.doi.org/10.5539/ass.v11n10p73

\begin{abstract}
The purpose of this study is to empirically examine the relationship between service quality and customer satisfaction in Vietnamese hotels, survey questionnaire was constructed with 23 service quality items covering 5 service quality dimensions based on SERVQUAL model. Data were collected from 432 guests of 33 three-star hotels in Vietnam in 2013. Analysis results indicate that Reliability, Responsiveness, Assurance, and Empathy significantly impact on the customer satisfaction. The study implies that service quality plays an important role as a driver for higher customer satisfaction level in hotel service. Managers would focus on Empathy, Reliability, Responsiveness, and Assurance to achieve high degree of customer satisfaction which leads to customer loyalty and business profit.
\end{abstract}

Keywords: customer satisfaction, hotel, service quality

\section{Introduction}

Quality has attracted the attention of practitioners and academicians over the years but mostly in the manufacturing sector at the first stage. Since 1980s, however, the importance of quality for business performance in service sector has been also widely recognized in the literature through the great impacts on different dimensions of business performance. To study service quality, several measurement frameworks were established such as Technique and functional quality model Gronroos (1984), SERVQUAL (Parasuraman et al., 1985, 1988), Synthesized model of service quality (Brogowicz et al., 1990); SERVPERF (Cronin \& Taylor, 1992), Antecedents and mediator model (Dabholkar et al., 2000). Based on those frameworks, researchers found the benefits of service quality include the improvement of customer satisfaction and customer retention, positive word of mouth, the decline in staff turnover and operating costs, the enlargement of market share, and the growth of profitability (Kandampully \& Suhartanto, 2000; Sureshchandar et al., 2002; Kang \& James, 2004; Ladhari, 2009). The researchers also highlighted the importance of service quality with direct effects on customer satisfaction as well as indirect effects on customer loyalty (Hossain, 2012; Al Khattab \& Aldehayyat, 2011; Karunaratne \& Jayawardena, 2010).

Tourism is often viewed as a "smokeless industry" bringing tremendous values to the global economies. Asia is one of amazing and most popular destinations for tourists which offer a wide-range of attractions in terms of landscape, culture, and people. Especially, tourism in ASEAN countries has seen considerable development by attracting a huge and increasing number of arrivals with 73.7 million tourists in 2010,81.2 million in 2011, and 89.2 million in 2012 (Association of Southeast Asian nations, 2014).

In Vietnam, tourism business is considered as a promising prospect to this nation's development. It welcomed more than 5 million visitors in 2010, more than 6 million visitors in 2011, and nearly 7 million visitors in 2012 (Association of Southeast Asian nations, 2014). Total revenue of tourism industry has increased rapidly from 4.8 billion USD in 2010 to 6.5 billion USD in 2011, and to 8 billion USD in 2012. It has contributed over 5\% to Vietnamese GDP and created jobs for more than 334,000 direct labors and approximately 710,000 indirect labors (Thornton, 2012). 
Hotel service is recently regarded as one of core businesses making up the tourism complex system which is one of the fastest growing industries in Vietnam during the past decade. The intensively competitive market requires hoteliers continuously renew and improve themselves to attract customers. In this context, the attention to service quality from the customer's perspective is considered as one of the most important factors deciding the success of tourism and hotel businesses. Therefore, the measurement of service quality and the evaluation of its impact on the customer satisfaction have been a great concerned topic for academics and practitioners in many service industries including tourism and hotel industries. To measure service quality in hotel, lodging, hospitality business, several frameworks have been developed such as LODGSERV (Knutson et al., 1990), LQI (J. M. Getty \& R. L. Getty, 2003) and HOLSERV (Mei et al., 1999); and many studies adopted these scales to evaluate perceived quality in hotel services such as Wilkins et al., (2007), Ladhari, (2009), Al Khattab and Aldehayyat (2011), Boonitt and Rompho (2012), Karunaratne and Jayawardena (2010), Hossain (2012), Markovic and Raspor (2010), Juwaheer (2004), Juwaheer and Ross (2003). These studies provided mixed results on the impacts of different service quality dimensions on customer satisfaction and customer loyalty in various regions including Asian countries. However, the application of such frameworks in measuring service quality in Vietnamese hotel businesses is still limited.

To fill this gap, our study is conducted to empirically investigate hotel service quality in Vietnam. The main objectives of this study are to measure perceived service quality at Vietnamese hotels and its impact on customer satisfaction.

The paper starts with reviewing the empirical literature of service quality and customer satisfaction. A simple analytical framework is introduced in the third section, which is followed by research methodology, data collection, measurement testing, and hypotheses testing. The last two sections are discussions and implications, and conclusions.

\section{Literature Review}

The importance of service quality for business performance has been recognized in the literature through the direct effect on customer satisfaction and the indirect effect on customer loyalty (Al Khattab and Aldehayyat, 2011). Various scales and indexes to measure service quality such as Technical and Functional Quality model (Gronroos, 1984), SERVQUAL (Parasuraman et al., 1985, 1988), Synthesized model of service quality (Brogowicz et al., 1990); SERVPERF (Cronin \& Taylor, 1992), Antecedents and mediator model (Dabholkar et al., 2000) have been developed and extensively used by academics and practitioners. Among them, SERVQUAL is often considered as the most commonly applied in a numerous empirical studies across various service industries and in many countries.

SERVQUAL scale was originally developed by Parasuraman et al. in 1985 by comparing expectations with perceptions on 10 service quality aspects. By 1988, this scale was further identified with 5 dimensions of service quality namely Tangible, Reliability, Responsiveness, Assurance and Empathy. These five dimensions are thus assessed by a total of 44 items in which 22 items to measure the general expectations of customers concerning a service; and the remaining 22 items to measure the perceptions of customers regarding the levels of service actually provided by the company within that service category (Ladhari, 2009).

However, SERVQUAL has been criticized on its confusion, and SERVPERF was proposed by Cronin and Taylor (1992) in which "expectation" - (E) component of SERVQUAL be discarded and instead "performance" - (P) component alone be measured by 22 items. Methodologically, the SERVPERF scale represents marked improvement over the SERVQUAL scale by reducing the number of items by 50 per cent, and being able to explain greater variance in the service quality measured through the use of single-item scale (Jain \& Gupta, 2004).

Although the SERVQUAL scale is a very useful instrument as its concept, it is still needed to be adapted for specific service industry. Guided by SERVQUAL, LODGSERV scale was specifically tailored to the lodging industry by Knutson et al. (1990). This scale initially contained 36 items designed to tap various aspects of the 5 service quality dimensions namely Tangible, Reliability, Responsiveness, Assurance, and Empathy. The items were used to measure consumers' expectations for service quality in a hotel experience. After three testing instruments including validity, reliability and utility, 10 of the original 36 questions were shown to not contribute meaning to the index, and final version of LODGSERV was completed with 26 question items. 
Table 1. Summary of empirical studies on hotel service quality

\begin{tabular}{|c|c|c|}
\hline Authors & Study & Survey instruments and data collection \\
\hline Hossain (2012) & $\begin{array}{l}\text { Impact of perceived } \\
\text { service quality on } \\
\text { satisfaction of tourists } \\
\text { visiting Cox's Bazar } \\
\text { in Bangladesh }\end{array}$ & $\begin{array}{l}\text { - } 5 \text { dimensions: Tangibles, Reliability, } \\
\text { Responsiveness, Assurance and } \\
\text { Empathy } \\
\text { - } 22 \text { question items, 5-point Likert scale } \\
\text { from "strongly disagree" to "strongly } \\
\text { agree" } \\
\text { - Sample size: } 385 \text { tourists }\end{array}$ \\
\hline $\begin{array}{l}\text { Boonitt \& } \\
\text { Rompho (2012) }\end{array}$ & $\begin{array}{l}\text { Measuring Service } \\
\text { Quality Dimensions } \\
\text { and comparing } \\
\text { between boutique and } \\
\text { business hotels in } \\
\text { Thailand }\end{array}$ & $\begin{array}{l}\text { - Customized SERVQUAL model with } \\
29 \text { indicators, 5-point Likert scale from } \\
\text { "very low" to "very high" } \\
\text { - Sample size: } 108 \text { responses }\end{array}$ \\
\hline $\begin{array}{l}\text { Al Khattab \& } \\
\text { Aldehayyat } \\
(2011)\end{array}$ & $\begin{array}{l}\text { Measuring } \\
\text { hotels'service quality } \\
\text { performance from } \\
\text { customer perspective } \\
\text { in Jordan }\end{array}$ & $\begin{array}{l}\text { - } 5 \text { dimensions: Tangibles, Reliability, } \\
\text { Responsiveness, Assurance and } \\
\text { Empathy } \\
\text { - } 26 \text { question items, 5-point Likert scale } \\
\text { from "strongly disagree" to "strongly } \\
\text { agree" } \\
\text { - Sample size: } 280 \text { responses }\end{array}$ \\
\hline $\begin{array}{l}\text { Markovic \& } \\
\text { Raspor (2010) }\end{array}$ & $\begin{array}{l}\text { Measuring perceived } \\
\text { service quality of } 15 \\
\text { hotels in the Opatija } \\
\text { Riviera (Croatia) to } \\
\text { determine the factor } \\
\text { structure of service } \\
\text { quality perception }\end{array}$ & $\begin{array}{l}\text { - } 4 \text { dimensions: Reliability, Empathy } \\
\text { and competence of staff, Accessibility, } \\
\text { Tangibles } \\
\text { - } 29 \text { question items, } 7 \text {-point Likert scale } \\
\text { from "very low perceptions" to "very } \\
\text { high perceptions" } \\
\text { - Sample size: } 253 \text { responses }\end{array}$ \\
\hline
\end{tabular}

Assessment of

Karunaratne \& customer satisfaction Jayawardena of a five-star hotel (2010)

Juwaheer

(2004)

Mauritius

Exploring perceptions of international

tourists about hotel service quality in Mauritius
- 5 dimensions: Tangibility, Reliability, Responsiveness, Assurance and Empathy.

- 49 question items, 5-point Likert scale - Sample size: 60 residential customers

- 9 dimensions: Reliability, Assurance, Extra room amenities, Staff communication and additional amenities sought, Room attractiveness and décor, Empathy, Staff outlook and accuracy, Food and service related, Hotel surroundings and environmental factors

- 39 question items, 5-point Likert scale from "very low expectation" to "very high expectation"

- Sample size: 410 international tourists

Assessing customers' expectations and perceptions of service provided by hotels of Mauritius

- Customized SERVQUAL with 39 attributes

- Sample size: 410 responses
Main findings

Five service quality dimensions have positively significant impact on customer satisfaction. The strongest factor is empathy, followed by responsiveness, reliability, assurance and tangibles.

Service quality was moderately low. Hotels were not able to deliver services as expected. Also, the customer expectation of the services of the boutique hotels was higher than that of the business hotels.

Hotel customers are expecting more improved services from the hotels in all service quality dimensions. They have the lowest perception scores on empathy and tangibles.

'Reliability,' 'empathy and competence of staff,' 'accessibility' and 'tangibles' are the key factors that best explained customers' expectations. Among the four dimensions, 'reliability' has emerged as the most important predictor of perceived service quality.

Majority of the customers expressed their satisfaction with the overall service they received from the hotel, especially regarding Tangibility, Responsiveness and Assurance. The hotel had not fulfilled the customers' satisfaction with regard to Reliability and Empathy.

Room attractiveness and décor have strongest affect perceptions of hotel guests' satisfaction, followed by Staff outlook and accuracy, Reliability, Hotel surroundings and environmental factors, Food and service related factors.
Customers' perception of service quality in Mauritius hotel industry fell short of their expectations, with the "empathy" dimension having largest gap. 
In 2003, another Lodging quality index (LQI) to assess customers' perception of quality delivery was proposed by J. M. Getty \& R. L. Getty (2003). The study began with the same 10 original dimensions that were used to develop SERVQUAL namely Tangibility, Reliability, Responsiveness, Competence, Courtesy, Credibility, Security, Access, Communication, and Understanding with initial 63-item instrument to measure customers' perception of delivered quality. After reliability and validity testing through empirical evidence, final lodging quality index (LQI) comprised 26 items covering 5 dimensions namely Tangibility, Reliability (includes original reliability and credibility dimensions), Responsiveness, Confidence (includes original competence, courtesy, security, and access dimensions), and Communication (includes original communication and understanding dimensions).

More significantly, Mei et al. in 1999 examined the dimensions of service quality in the hospitality industry and proposed HOLSERV scale by extending the SERVQUAL scale to include 27 items with 8 new items. This study tested the reliability and validity of HOLSERV and determined which dimension is the best predictor of overall service quality. Key findings of the study are that service quality is represented by three dimensions in the hospitality industry, relating to employees (behavior and appearance), tangibles and reliability, and the best predictor of overall service quality is the dimensions referred to "employees".

Customer satisfaction has become a vital concern for companies and organizations in their efforts to improve product and service quality, and maintain customer loyalty within a highly competitive marketplace (Awwad, 2012). Through previous three decades, a number of customer satisfaction indicators have been developed and applied across different countries. The first national customer satisfaction index was introduced in 1989 namely Swedish customer satisfaction barometer (SCSB) by Claes Fornell (1992). In 1996, Fornell developed the American Customer Satisfaction Index (ACSI) (Fornell, 1996) based on SCSB which then has been become increasingly well-adopted scale in many countries. Moreover, the European Customer Satisfaction Index (ECSI) was established and introduced in 11 European countries (Turkyılmaz, 2007). In these scales, customer satisfaction items were identified based on the popular view point about customer satisfaction stated that satisfaction is associated with performance that fulfills (equal to or above) expectations (Heung, 2000). In other word, customer satisfaction items will measure whether or not the quality of a service meets a customer's expectations.

LODGSERV (Knutson et al., 1990), LQI (J. M. Getty \& R. L. Getty, 2003), and HOLSERV (Mei et al., 1999) are all developed on the basis of SERVQUAL scale to measure service quality in the lodging, hospitality industry. Moreover, there have been numerous empirical studies supporting for the validity of the SERVQUAl model in the hotel service industry (Wilkins et al., 2007; Ladhari, 2009). These study adapted SERVQUAL scale with some modifications to measure hotel service quality such as Tsang and Qu (2000), Al Khattab \& Aldehayyat (2011), Boonitt \& Rompho (2012), Karunaratne \& Jayawardena (2010), Juwaheer \& Ross (2003). Moreover, there are studies which not only apply SERVQUAL to measure hotel service quality, but also use this measurement to investigate the impact of service quality on customer satisfaction such as Hossain (2012), Markovic \& Raspor (2010), Juwaheer (2004).

In Vietnam, there are a few studies investigating the linkage between service quality and customer satisfaction in Vietnamese tourism industry such as Analyzing factors that affect tourists' satisfaction with service quality by $\mathrm{Vu}$ (2012), Examining domestic tourists' satisfaction with tourism service by Dinh et al., (2011). However, these studies focus on several specific regions and need more intensive studies.

To address this need, the study, based on SERVQUAL model with some customizations, aims to empirically examine the relationship between service quality and customer satisfaction in Vietnamese hotels.

\section{Analytical Framework}

SERVQUAL scale (Parasuraman et al., 1988) is one of the most widely used instruments to measure service quality in various service fields including hotel business (Hossain, 2012; Boonitt \& Rompho, 2012; Al Khattab \& Aldehayyat, 2011). This study adopted SERVQUAL scale with some customizations to measure perceived service quality as well as examine the relationship between service quality and customer satisfaction in Vietnamese hotels.

The analytical framework is proposed as following: 


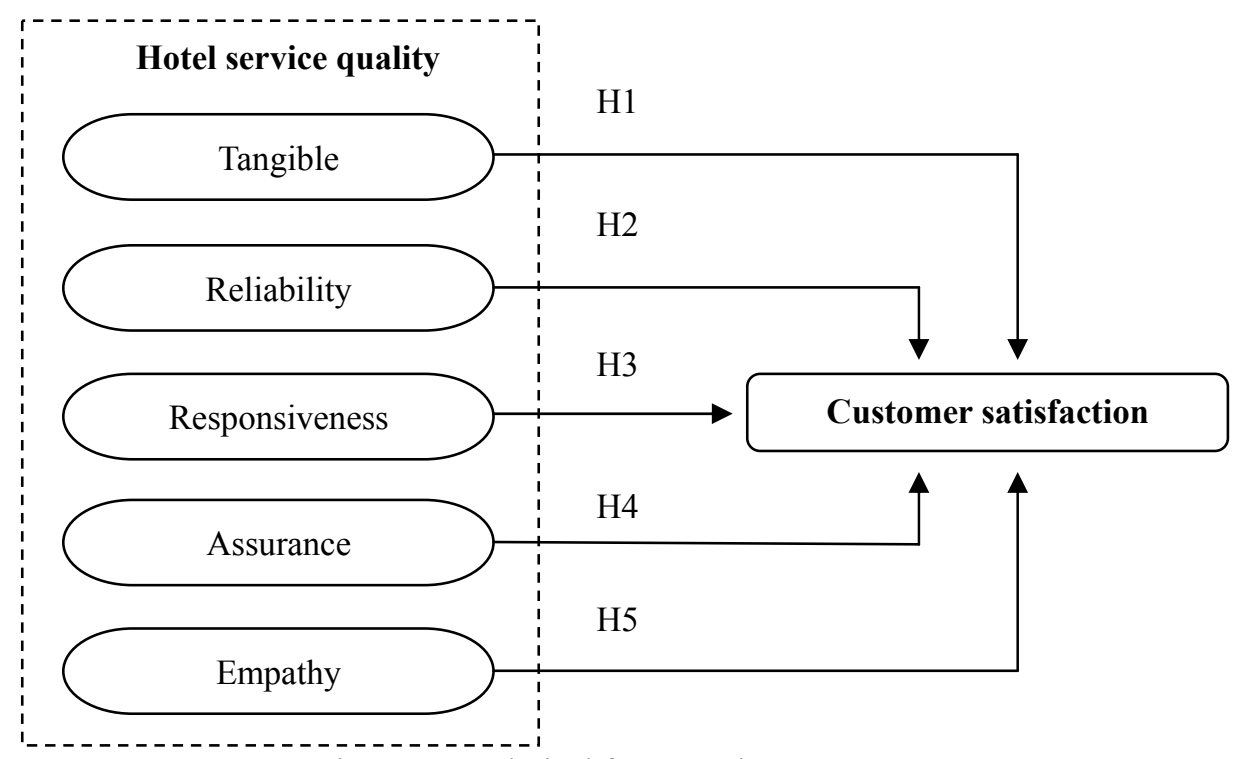

Figure 1. Analytical framework

This scale measures hotel service quality through five distinct dimensions namely Tangible, Reliability, Responsiveness, Assurance, and Empathy. These dimensions have been also extensively accepted and applied by many academics and practicing managers in various industries.

- Tangible: the appearance of hotel and hotel staff, physical facilities at hotel/rooms, visual materials for customers.

- Reliability: hotel's ability to perform services accurately and on time right at the first time.

- Responsiveness: hotel's willingness and flexible to serve and help customers.

- Assurance: hotel's ability to build trust in customers about hotel services, hotel staff's knowledge and skills.

- Empathy: hotel's attentions and cares to each individual customer.

Service quality measures how well the delivered service could match customer's expectations while delivery service quality refers to meeting and satisfying customer's expectation consistently and positively (Parasuraman et al., 1985). Based on literature, several empirical studies found the linkage between customer satisfaction with Tangible (Al Khattab \& Aldehayyat, 2011), Empathy (Hossain, 2012; Al Khattab \& Aldehayyat, 2011), Responsiveness (Karunaratne \& Jayawardena, 2010), Relibility (Markovic \& Raspor, 2010). The main target of this study is to investigate the relationship between service quality and customer satisfaction. Therefore, we proposed five hypotheses for this research model as followed:

- H1: Tangible component of service quality has positive impact on customer satisfaction;

- H2: Reliability component of service quality has positive impact on customer satisfaction;

- H3: Responsiveness component of service quality has positive impact on customer satisfaction;

- H4: Assurance component of service quality has positive impact on customer satisfaction;

- H5: Empathy component of service quality has positive impact on customer satisfaction.

After reviewing literature to model the analytical framework, a questionnaire was developed as an adapted version of SERVQUAL (Parasuraman et al., 1988), and referenced to LODGSERV (Knutson et al., 1990), LQI (J. M. Getty \& R. L. Getty, 2003), and HOLSERV (Mei et al., 1999). The questionnaire was first developed in English, and then translated into Vietnamese to be conveniently used in wide survey.

The original questionnaire for this study comprised 30 question items on service quality and customer satisfaction. Then, a pilot testing with a convenient sample of 36 MBA students was conducted to get feedbacks on how easy to answer the questionnaire. Together with in-depth interviews with academics and practitioners in quality management and hotel operation fields, a more comprehensive questionnaire version was completed by adding 3 new question items and rejecting 10 unclear question items. 
The questionnaire was divided into 3 parts. The first part contained questions relating to socio-demographic data about respondents. The second part was designed to measure respondents' perception about service quality offered by hotels. The remaining part assessed respondents' perception regarding to their satisfaction about hotel services. This measurement bases on a five-point Likert scale $(1=$ strongly disagree, $3=$ neither agree nor disagree, $5=$ strongly agree). The survey respondent is a mixed sample of individual and group visitors who stayed at least one night at examined hotel in the period from May 2013 to June 2013.

Data collected will firstly be tested the scale reliability and validity. Then, regression analysis will be taken to test the relationship between service quality and customer satisfaction of three-star hotels in Da Nang.

\section{Data Collection and Measurement Test}

\subsection{Data Collection}

Data in this research were acquired from guests of 33 three-star hotels in Da Nang city, one of the most favorite places for tourists in Vietnam, an emerging city which has the highest developing speed and be ranked as the most competitive region in Vietnam (CBRE, 2011). Moreover, this destination is more well-known and attractive by hosting many famous events such as International Fireworks Competition, International Marathon Competition, Miss Vietnam, and Culture Festivals. According to the statistics from Da Nang Culture, Sports and Tourism Department, Da Nang welcomed 2.65 million arrivals including 2.02 million Vietnamese visitors and 0.63 million foreign visitors in 2012 which increase by $12 \%$ compared to 2011 .

Huge contributions of three-star hotel, four-star hotel and five-star hotel classes for the economic growth in this region have been taken under high consideration by many economists and researchers (Da Nang Culture, Sports and Tourism Department, 2012). According to statistics from CBRE market review 2012, three-star hotels in Da Nang present a largest serving capacity with 33 hotels and 1.984 rooms, followed by 8 five-star hotels with 1.649 rooms, and 3 four-star hotels with 563 rooms (CBRE, 2012). Statistics for three-star hotels in this region provide evidence for the highest occupancy rate of $66.4 \%$ in 2011 (Thornton, 2012). However, three-star hotels are the middle class hotels with limited investment and attention to service quality. Besides, literature reviewing in Vietnam shows that there was not official research addressing quality aspects in Vietnamese three-star hotels despite high necessity of this research topic in the national context in recent years.

Among 500 questionnaires provided to customers, 447 responses were collected. After inputting data and screening questionnaires, 15 missing responses were rejected from the data set and the remaining 432 valid responses have been used to analyze by SPSS 20.0. The sample data indicates that the majority respondent group $(88.2 \%)$ is the young tourist with the range of age between 20 to 30 years old. In addition, $89.6 \%$ of respondents staying at three-star hotels in Da Nang with the purpose of travelling while just $8.6 \%$ of them staying there with business trip purpose. Over $50 \%$ of respondents has a rather high income per month with about 300USD to 600USD. The percentage of guests with income under 300USD or ranging from 600USD to 1000USD is much smaller with $25.9 \%$ and $17.6 \%$, respectively.

Table 2. Demographic profiles of respondents

\begin{tabular}{llllll}
\hline Age & $\%$ & Purpose & $\%$ & Income per month & $\%$ \\
\hline Under 20 & 3.7 & Travelling & 89.6 & Under 300USD & 25.9 \\
$20-30$ & 88.2 & Business trip & 8.6 & $300-600$ USD & 51.6 \\
$31-40$ & 6.2 & Other purpose & 1.9 & $600-1000$ USD & 17.6 \\
Over 40 & 1.6 & & & Over 1000USD & 4.9 \\
N/A & 0.2 & & & & \\
\hline
\end{tabular}

\subsection{Measurement Test}

The first step of measurement testing process is reliability test. One method to measuring reliability is through internal consistency which refers to the degree of inter-correlation among items that comprise the measure or summated scale (Flynn et al., 1990). The most widely accepted measure of internal consistency is Cronbach's alpha which is the average of the correlation coefficient of each item with each other item (Cronbach \& Meehl, 1955). In this study, calculated Cronbach's alpha values for all scale exceeds the minimum acceptable alpha value of 0.60 (Nunnally, 1978; Phan \& Matsui, 2012). Most of the scales have alpha value greater than 0.70 indicating that the scales are internally consistent. 
Table 3. Reliability test

\begin{tabular}{lllll}
\hline Measurement constructs & Number of items & Cronbach's Alpha & Mean & Standard deviation \\
\hline Tangible & 6 & 0.93 & 3.58 & 0.86 \\
Reliability & 4 & 0.85 & 3.69 & 0.77 \\
Responsiveness & 3 & 0.67 & 3.73 & 0.74 \\
Assurance & 4 & 0.83 & 3.79 & 0.79 \\
Empathy & 4 & 0.86 & 3.69 & 0.79 \\
\hline
\end{tabular}

Table 4. Contents of questionnaire survey

\begin{tabular}{|c|c|c|}
\hline Code & Attributes & References/Origin \\
\hline $\mathbf{T}$ & TANGIBLE & \\
\hline T1 & Convenient location & New \\
\hline $\mathrm{T} 2$ & Comfortable facilities and equipment & $\begin{array}{l}\text { SERVQUAL (Parasuraman et al., 1988), LODGSERV } \\
\text { (Knutson et al., 1990), HOLSERV (Mei et al., 1999), LQI } \\
\text { (J. M. Getty \& R. L. Getty, 2003) }\end{array}$ \\
\hline T3 & Appealing decoration & LODGSERV (Knutson et al., 1990) \\
\hline T4 & Neat appearance staff & $\begin{array}{l}\text { SERVQUAL (Parasuraman et al., 1988), LQI (J. M. Getty } \\
\& \text { R. L. Getty, 2003) }\end{array}$ \\
\hline T5 & Visually presented brochures and directories & Customized from HOLSERV (Mei et al., 1999) \\
\hline T6 & Appropriate environment for taking a rest & Customized from LODGSERV (Knutson et al., 1990) \\
\hline $\mathbf{R}$ & RELIABILITY & \\
\hline R1 & Performs service accurately & HOLSERV (Mei et al., 1999) \\
\hline R2 & Provides service on time & $\begin{array}{l}\text { SERVQUAL (Parasuraman et al., 1988), LODGSERV } \\
\text { (Knutson et al., 1990), HOLSERV (Mei et al., 1999) }\end{array}$ \\
\hline R3 & Solves problem sincerely & SERVQUAL (Parasuraman et al., 1988), \\
\hline R4 & Keeps confidential records & New \\
\hline $\mathbf{S}$ & RESPONSIVENESS & \\
\hline S1 & Willingness to serve guests & $\begin{array}{l}\text { SERVQUAL (Parasuraman et al., 1988), HOLSERV (Mei } \\
\text { et al., 1999), LQI (J. M. Getty \& R. L. Getty, 2003) }\end{array}$ \\
\hline $\mathrm{S} 2$ & Availability to respond to guests' requests & $\begin{array}{l}\text { SERVQUAL (Parasuraman et al., 1988), HOLSERV (Mei } \\
\text { et al., 1999), LQI (J. M. Getty \& R. L. Getty, 2003) }\end{array}$ \\
\hline $\mathrm{S} 3$ & Flexibility according to guests' demands & Customized from LODGSERV (Knutson et al., 1990) \\
\hline $\mathbf{A}$ & ASSURANCE & \\
\hline A1 & Guests feel safe and secure in their stay & $\begin{array}{l}\text { HOLSERV (Mei et al., 1999), LQI (J. M. Getty \& R. L. } \\
\text { Getty, 2003) }\end{array}$ \\
\hline A2 & $\begin{array}{l}\text { Staff with knowledge to provide guests } \\
\text { information about surrounding areas } \\
\text { (shopping, museum, place of interest...) }\end{array}$ & Customized from LQI (J. M. Getty \& R. L. Getty, 2003) \\
\hline A3 & Staff with occupational skills & $\begin{array}{l}\text { Customized from HOLSERV (Mei et al., 1999) and } \\
\text { LODGSERV (Knutson et al., 1990) }\end{array}$ \\
\hline A4 & Staff are courteous and polite & $\begin{array}{l}\text { SERVQUAL (Parasuraman et al., 1988), HOLSERV (Mei } \\
\text { et al., 1999), LQI (J. M. Getty \& R. L. Getty, 2003) }\end{array}$ \\
\hline $\mathbf{E}$ & EMPATHY & \\
\hline E1 & Provides guests individual attention & $\begin{array}{l}\text { SERVQUAL (Parasuraman et al., 1988), HOLSERV (Mei } \\
\text { et al., 1999) }\end{array}$ \\
\hline E2 & Understands guest specific needs & $\begin{array}{l}\text { SERVQUAL (Parasuraman et al., 1988), HOLSERV (Mei } \\
\text { et al., 1999) }\end{array}$ \\
\hline E3 & $\begin{array}{l}\text { Positive attitude when recieve feedback } \\
\text { from guests }\end{array}$ & New \\
\hline E4 & Healthful menu & LODGSERV (Knutson et al., 1990) \\
\hline
\end{tabular}


The next step of measurement testing process is validity test to measure whether the item or scale truly measures what it is supposed to measure and whether it measures nothing else. Validity test will be taken with content validity and construct validity test.

Content validity of the questionnaire is confirmed by intensive literature reviewing and by opinions from experts and operators in hotel industry. The main valuable references to construct question items for this study are SERVQUAL (Parasuraman et al., 1988) - a multiple-item scale for measuring consumer perceptions of service quality, LODGSERV (Knutson et al., 1990) - a service quality index for the lodging industry, LQI (J. M. Getty \& R. L. Getty, 2003) - lodging quality index to assess customers' perceptions of quality delivery, and HOLSERV (Mei et al., 1999) - a service quality measurement scale for the hospitality industry. Moreover, many empirical studies have applied the above scales to measure service quality in hotels such as Tsang \& Qu (2000), Al Khattab \& Aldehayyat (2011), Boonitt \& Rompho (2012), Karunaratne \& Jayawardena (2010), Juwaheer \& Ross (2003) are also valuable references for this study.

Construct validity is tested through factor analysis to ensure that the scale is an appropriate operational definition of an abstract variable (Flynn et al., 1990). In this study, factor analysis is conducted with 5 summated scales Tangible, Reliability, Responsiveness, Assurance, and Empathy - simultaneously. In KMO and Bartlett's Test, KMO value measuring the sampling adequacy equals to 0.840 (greater than 0.5 ) with significant value is 0.000 . These numbers confirm the validity of data for exploratory factor analysis. By Principal Component Analysis and Varimax with Kaiser Normalization rotation method, 5 components are extracted with greater than 1 eigenvalues. The cumulative of variance is $75.75 \%$ which means that these 5 components explain $75.75 \%$ of service quality variance. Factor loadings of all service quality items which indicate correlation between the variables and the factor are greater than 0.5 . These results would confirm that data are valid and could be use for further analysis.

Table 5. Results of factor analysis

\begin{tabular}{|c|c|c|c|c|c|}
\hline & Compo & & & & \\
\hline & 1 & 2 & 3 & 4 & 5 \\
\hline T1 & 0.811 & & & & \\
\hline $\mathrm{T} 2$ & 0.740 & & & & \\
\hline $\mathrm{T} 3$ & 0.679 & & & & \\
\hline $\mathrm{T} 4$ & 0.862 & & & & \\
\hline T5 & 0.860 & & & & \\
\hline T6 & 0.762 & & & & \\
\hline R1 & & & 0.782 & & \\
\hline R2 & & & 0.648 & & \\
\hline R3 & & & 0.569 & & \\
\hline R4 & & & 0.581 & & \\
\hline $\mathrm{S} 1$ & & & & & 0.846 \\
\hline S2 & & & & & 0.734 \\
\hline S3 & & & & & 0.557 \\
\hline A1 & & & & 0.683 & \\
\hline A3 & & & & 0.763 & \\
\hline A4 & & & & 0.728 & \\
\hline A5 & & & & 0.605 & 0.501 \\
\hline E1 & & 0.783 & & & \\
\hline E2 & & 0.747 & & & \\
\hline E3 & & 0.798 & & & \\
\hline E4 & & 0.849 & & & \\
\hline Eigenvalues & 9.501 & 2.085 & 1.911 & 1.399 & 1.012 \\
\hline$\%$ of Variance & 45.242 & 9.930 & 9.098 & 6.663 & 4.821 \\
\hline Cumulative Variance & 45.242 & 55.172 & 64.27 & 70.933 & 75.754 \\
\hline
\end{tabular}




\section{Data Analysis}

Regression analysis is conducted to examine the relationship between hotel service quality and customer satisfaction and to test the hypotheses as set in the above section. A multiple regression model is constructed with customer satisfaction as the dependent variable and Tangible, Reliability, Responsiveness, Assurance, and Empathy as the independent variables.

Prior to regression analysis, correlation analysis is conducted and the results are presented in Table 6 . We found the significant correlation between the customer satisfaction and all of 5 service quality dimensions. In addition, we found also the high correlation coefficients between service quality dimensions. Therefore, the Variance Inflation Factor (VIF) that measures the inflation in parameter estimate due to the collinearities among independent variables is calculated for the regression model. The value of VIF for each variable is presented in Table 7. By setting the acceptable value for VIF at 4 as suggested in the literature, it is found that model variables are within the VIF limit indicating that their multi-collinearities do not have an undue influence on least squares estimates. As the result, all the variables are retained in the model for further analysis.

Table 6. Correlation analysis

\begin{tabular}{|c|c|c|c|c|c|c|c|}
\hline & & $\mathbf{T}$ & $\overline{\mathbf{R}}$ & $\mathbf{A}$ & $\mathbf{S}$ & $\mathbf{E}$ & CS \\
\hline \multirow{2}{*}{$\mathrm{T}$} & \multirow{2}{*}{ Pearson Correlation Sig. (2-tailed) } & \multirow{4}{*}{1.000} & .595 & .485 & .440 & .467 & .479 \\
\hline & & & 0.000 & 0.000 & 0.000 & 0.000 & 0.000 \\
\hline \multirow{2}{*}{$\mathrm{R}$} & \multirow{2}{*}{ Pearson Correlation Sig. (2-tailed) } & & 1000 & .567 & 443 & .533 & .538 \\
\hline & & & 1.000 & 0.000 & 0.000 & 0.000 & 0.000 \\
\hline \multirow{2}{*}{ A } & \multirow{2}{*}{ Pearson Correlation Sig. (2-tailed) } & & & 1000 & 615 & .453 & .525 \\
\hline & & & & 1.000 & 0.000 & 0.000 & 0.000 \\
\hline \multirow{2}{*}{$\mathrm{S}$} & \multirow{2}{*}{ Pearson Correlation Sig. (2-tailed) } & & & & 1000 & .403 & .501 \\
\hline & & & & & & 0.000 & 0.000 \\
\hline $\mathrm{E}$ & Pearson Correlation Sig. (2-tailed) & & & & & 1.000 & .632 \\
\hline $\mathrm{CE}$ & Pearson Correlation Sig (2-tailed) & & & & & & 1.000 \\
\hline
\end{tabular}

Table 7. Regression analysis

\begin{tabular}{|c|c|c|c|c|c|}
\hline $\mathbf{R}$ & 0.716 & & & & \\
\hline R square & 0.512 & & & & \\
\hline \multirow[t]{2}{*}{ Sig. } & 0.000 & & & & \\
\hline & B & t & Sig. & $\begin{array}{l}\text { Collinearity Statistics } \\
\text { Tolerance }\end{array}$ & VIF \\
\hline (Constant) & 0.561 & 3.501 & 0.001 & & \\
\hline $\mathrm{T}$ & 0.070 & 1.766 & 0.078 & 0.582 & 1.717 \\
\hline $\mathrm{R}$ & 0.131 & 2.764 & 0.006 & 0.502 & 1.990 \\
\hline S & 0.174 & 3.835 & 0.000 & 0.586 & 1.705 \\
\hline A & 0.121 & 2.656 & 0.008 & 0.500 & 1.999 \\
\hline $\mathrm{E}$ & 0.382 & 9.520 & 0.000 & 0.652 & 1.533 \\
\hline
\end{tabular}

If we take the value of $\mathrm{R}^{2}$ to be the explanation power of regression model, these 5 service quality variables can clearly explain $51.2 \%$ of the variation of the customer satisfaction. Considering the beta coefficient of each independent variable and its significant level, we found that 4 intangible components of service quality including Reliability, Responsiveness, Assurance, and Empathy show the significant impact on Customer satisfaction (at the 5\% significant level). Among them, Empathy expresses the strongest impact on Customer satisfaction with highest coefficient value of 0.382 . Reliability, Responsiveness and Assurance represent the relative smaller impacts with coefficient values of $0.131,0.174$, and 0.121 , respectively. Tangible component, however, is the only independent variable which does not indicate the significant impact on customer satisfaction at the $5 \%$ level. 
Table 8 . The results of hypotheses testing

\begin{tabular}{ll}
\hline Hypotheses & Result \\
\hline H1: Tangible component of service quality has positive impact on customer satisfaction & $\begin{array}{l}\text { Not } \\
\text { supported }\end{array}$ \\
H2: Reliability component of service quality has positive impact on customer satisfaction & Supported \\
H3: Responsiveness component of service quality has positive impact on customer satisfaction & Supported \\
H4: Assurance component of service quality has positive impact on customer satisfaction & Supported \\
H5: Empathy component of service quality has positive impact on customer satisfaction & Supported \\
\hline
\end{tabular}

The regression results would support hypotheses related with Reliability, Responsiveness, Assurance, and Empathy while would not support hypothesis related to Tangible dimension.

\section{Discussions and Implications}

This study adopted SERVQUAL approach to measure perceived service quality and its impact on customer satisfaction in Vietnamese hotels. A framework with comprehensive questionnaire consists of 21 question items.

The research results demonstrate that the service quality is a strong driver for customer satisfaction in hotel service in Vietnam. Among 5 quality dimensions, 4 intangible ones represent the significant impacts on the customer satisfaction whereas tangible is the only one does not reveal this clear impact. A similar conclusion is that the tourists would evaluate the importance of intangible elements of service quality higher than the tangible elements can be found in the research on service quality in UK holiday market by Ekinci et al. (2003).

Data analysis result stresses the most significant impact of Empathy on Customer satisfaction. Empathy refers to providing customers individual attention, understanding customer specific needs, having positive attitude when recieve feedback from customers, and providing healthful menu. That means the hotels can considerably increase their customer satisfaction level if they may better perform their empathy. This result was supported by the research in Bangladesh's tourism industry of Hossain (2012) which applied SERVQUAL scale to measure service quality and examine the impact of these service quality dimensions on customer satisfaction. This research result stressed Empathy with strongest impact on customer satisfaction.

Together with Empathy, three remaining intangible quality dimensions namely Responsiveness, Reliability, and Assurance express positively significant influence on Customer satisfaction. Among these three dimensions, Responsiveness which refer to the willingness to serve customers, availability to respond to customers' requests and flexibility to meet customers' demands has the strongest impact on customer satisfaction. Reliability contains attributes relating to performing services on time and accurately, solving problem sincerely, and keeping records confidentially is the next strong impact dimension; followed by Assurance which regards to customers' feeling safe and secure, staff's knowledge of surrounding areas, staff's occupational skills and staff's courteous attitude. This finding is highlighted in the research by Hossain (2012). Besides, Knutson et al. (1990) also supported for this finding by pointing out consumers' consistently high expectations for Reliability and Assurance dimensions which refer to consistent and on time services, quickly corrected problems, trained employees, knowledgeable staff, and customers' comfortable feelings. Moreover, Mei et al. (1999) obtained similar results of reflecting important influence from Employee dimensions which relating to prompt service, willingness to help, confident in the delivery of service, polite, knowledgeable, skillful, caring, understanding, sincere, neat and professional employees, and Reliability dimensions which referring to keeping promises, accurate and timely service, safe and secure stay. Furthermore, in the research on international tourists' perceptions of hotel operations in Mauritius by Juwaheer (2004), the research result also illustrated reliability factor, staff outlook and accuracy as important service dimensions affecting hotel customers' satisfaction.

The important role of 4 intangible quality dimensions implies suggestions for hoteliers to strongly focus on improving these quality dimensions to better gain customer satisfaction. It can be seen that these quality dimensions mostly rely on hotel staff's knowledge and attitude. One concerning suggestions for hoteliers is that they should appropriately allocate resources to provide training for hotel staff. As a result, hotel staff will be more confident with occupational skills and knowledge to serve and help customers.

Different from the four intangible quality dimension, Tangible represent a non-significant impact on the customer satisfaction although it also has positive correlation with customer satisfaction. It may be explained that hotels in Da Nang are mostly constructed in some recent years with quite new facilities and equipments so that customers do not regard this dimension as a differentiation factor among different hotels when they make 
decision. However, many previous studies found Tangible as one of significant factors affecting customer satisfaction such as Hossain (2012), Mei et al. (1999), and Juwaheer (2004). Especially, Juwaheer (2004) indicated that Room attractiveness and décor is the most significant factor affecting customer satisfaction. Therefore, hoteliers also should not ignore this dimension in their operations.

One limitation of this study is that the survey was conducted with guests of three-star hotels in Da Nang city. Moreover, time period to collected data were mostly in two months of tourism season - May and June 2013, with limited valid responses of 432 ones. Thus, some conclusions may be improved in other more extensive studies.

Despite these limitations, the study contributes to enrich the literature of service quality and customer satisfaction from a customer perspective. It enhances understanding of service quality and its impacts on customer satisfaction in Vietnamese hotels. The findings and implications will benefit hoteliers working in Vietnam who want to increase competitive advantage through quality dimensions.

In further research, this empirical evidence may be improved and better represent for hotel industry in any regions in Vietnam or even in the whole Vietnam with larger sample and during-year data collection. Besides, further research may deeply examine whether items used in this study are suitable to measure service quality in hotels at other classes such as four-star hotels, five-star hotels. Additionally, different demographic variables may be taken under the consideration as controlling variables to discuss the different impacts of service quality on customer satisfaction among different sample groups.

\section{Conclusions}

This study adopted SERVQUAL to empirically investigate the impact of service quality components on customer satisfaction in Vietnamese hotel business. Data were collected from an extensive survey with customers from 33 three-star hotels in Vietnam. Analysis results indicated that the strong relationship between service quality dimensions and customer satisfaction. Beside the importance of image, advertising, and promotion factor, service quality plays an important role as a driver for higher customer satisfaction level in service enterprises.

Four intangible components namely Empathy, Reliability, Responsiveness, and Assurance stress statistically significant impacts on customer satisfaction with significant level at 5\%. Empathy illustrates strongest impact on customer satisfaction with the highest beta coefficient value, followed by Responsiveness, Reliability, and Assurance, respectively. Tangible, however, is the only factor that does not reveal a statistical impact on customer satisfaction. This result indicates that service quality confirms its role as an important driver of customer satisfaction which leads to customer loyalty and the hotels' profits. Therefore, service quality should be taken into high consideration in both academic and practical activities.

\section{References}

Al Khattab, S. A., \& Aldehayyat, J. S. (2011). Perceptions of Service Quality in Jordanian Hotels. International Journal of Business and Management, 6(7), 226-233. http://dx.doi.org/10.5539/ijbm.v6n7p226

Association of Southeast Asian Nations. (2014). Tourists arrivals in ASEAN by selected partner country/region . ASIAN Statistics. Retrieved from http://www.asean.org/news/item/tourism-statistics

Awwad, M. S. (2012). An application of the American Customer Satisfaction Index (ACSI) in the Jordanian mobile phone sector. The TQM Journal, 24(6), 529-541. http://dx.doi.org/10.1108/17542731211270098

Boonitt, S., \& Rompho, N. (2012). Measuring Service Quality Dimensions: An Empirical Analysis of Thai Hotel Industry. International Journal of Business Administration, 3(5), 52-63. http://dx.doi.org/10.5430/ijba. v3n5p52

Brogowicz, A. A., Delene, L. M., \& Lyth, D. M. (1990). A synthesised service quality model with managerial implications. International Journal of Service Industry Management, 1(1), 27-44. http://dx.doi.org/10.1108/ 09564239010001640

CBRE. (2011). MarketView Da Nang. CB Richard Ellis Vietnam.

CBRE. (2012). MarketView Da Nang. CB Richard Ellis Vietnam.

Cronbach, L. J., \& Meehl, P. E. (1955). Construct validity in Psychological Tests. Psychological Bulletin, 52, 281-302. http://dx.doi.org/10.1037/h0040957

Cronin, J. J., \& Taylor, S. A. (1992). Measuring service quality: A reexamination and extension. Journal of Marketing, 56(3), 55-68. http://dx.doi.org/10.2307/1252296

Dabholkar, P. A., Shepherd, C. D., \& Thorpe, D. I. (2000). A comprehensive framework for service quality: An 
investigation of critical conceptual and measurement issues through a longitudinal study. Journal of Retailing, 76(2), 131-139. http://dx.doi.org/10.1016/S0022-4359(00)00029-4

Dinh, C. T., Pham, L. H. N., \& Truong, Q. D. (2011). Đánh giá mức độ hài lòng của khách nội địa đối với du lịch tỉnh Sóc Trăng. Tạp chi Khoa Học, 20(a), 199-209.

Ekinci, Y., Prokopaki, P., \& Cobanoglu, C. (2003). Service quality in Cretan accommodations: Marketing strategies for the UK holiday market. International Journal of Hospitality Management, 22(1), 47-66. http://dx.doi.org/10.1016/S0278-4319(02)00072-5

Flynn, B., Sakakibara, S., Schroeder, R., Bates, K., \& Flynn, E. (1990). Empirical research methods in operations management. Journal of Operations Management, 9(2), 250-284. http://dx.doi.org/10.1016/0272 $-6963(90) 90098-X$

Fornell, C. (1992). A national customer satisfaction barometer: The Swedish experience. Journal of Marketing, 56(1), 6-21. http://dx.doi.org/10.2307/1252129

Fornell, C., Johnson, M., Anderson, E., Cha, J., \& Bryant, B. (1996). The American Customer Satisfaction Index: Nature, purpose, and findings. Journal of Marketing, 60(4), 7-18. http://dx.doi.org/10.2307/1251898

Getty, J. M., \& Getty, R. L. (2003). Lodging quality index (LQI): Assessing customers' perceptions of quality delivery. International Journal of Contemporary Hospitality Management, 15(2), 94-104. http://dx.doi.org/ $10.1108 / 09596110310462940$

Gronroos, C. (1984). A service quality model and its marketing implications. European Journal of Marketing, 18(4), 36-44. http://dx.doi.org/10.1108/EUM0000000004784

Heung, V. C. S. (2000). Satisfaction levels of mainland Chinese travelers with Hong Kong hotel services. International Journal of Contemporary Hospitality Management, 12(5), 308-315. http://dx.doi.org/10.1108/ 09596110010339689

Hossain, M. J. (2012). Impact of service quality on customer satisfaction: A case of tourism industry in Bangladesh. International Journal of Research in Finance \& Marketing, 2(2), 1-25.

Jain, S. K., \& Gupta, G. (2004). Measuring Service Quality: SERVQUAL vs. SERVPERF Scales. Vikalpa, 29(2), 25-35.

Juwaheer, T. D. (2004). Exploring international tourists' perceptions of hotel operations by using a modified SERVQUAL approach-a case study of Mauritius. Managing Service Quality, 14(5), 350-364. http://dx.doi. org/10.1108/09604520410557967

Juwaheer, T. D., \& Ross, D. L. (2003). A study of hotel guest perceptions in Mauritius. International Journal of Contemporary Hospitality Management, 15(2), 105-115. http://dx.doi.org/10.1108/09596110310462959

Kandampully, J., \& Suhartanto, D. (2000). Customer loyalty in the hotel industry: The role of customer satisfaction and image. Managing Service Quality, 16(6), 346-351. http://dx.doi.org/10.1108/095961100103 42559

Kang, G. D., \& James, J. J. (2004). Service quality dimensions: An examination of Gro"nroos's service quality model. Managing Service Quality, 14(4), 266-277. http://dx.doi.org/10.1108/09604520410546806

Karunaratne, W. M. K. K., \& Jayawardena, L. N. A. C. (2010). Assessment of Customer Satisfaction in a Five Star Hotel-A Case Study. Tropical Agricultural Research, 21(3), 258-265.

Knutson, B., Stevens, P., Wullaert, C., Patton, M., \& Yokoyama, F. (1990). Lodgserv: A Service Quality Index for the Lodging Industry. Hospitality Research Journal, 14(2), 227-284.

Ladhari, R. (2009a). A review of twenty years of SERVQUAL research. International Journal of Quality and Service Sciences, 1(2), 172-198. http://dx.doi.org/10.1108/17566690910971445

Ladhari, R. (2009b). Service quality, emotional satisfaction, and behavioural intentions: A study in the hotel industry. Managing Service Quality, 19(3), 308-331. http://dx.doi.org/10.1108/09604520910955320

Markovic, S., \& Raspor, S. (2010). Measuring Perceived Service Quality Using Servqual: A Case Study of the Croatian Hotel Industry. Management, 5(3), 195-209.

Mei, A. W. O., Dean, A. M., \& White, C. J. (1999). Analyzing service quality in the hospitality industry. Managing Service Quality, 9(2), 136-143. http://dx.doi.org/10.1108/09604529910257920

Nunnally, J. (1978). Psychometric theory. McGraw Hill, New York. 
Parasuraman, A., Zeithaml, V. A., \& Berry, L. L. (1985). A conceptual model of service quality and its implications for future research. Journal of Marketing, 49(Fall), 41-50. http://dx.doi.org/10.2307/1251430

Parasuraman, A., Zeithaml, V. A., \& Berry, L. L. (1988). SERVQUAL: A multiple-item scale for measuring consumer perceptions of service quality. Journal of Retailing, 64(Spring), 12-37.

Phan, C. A., \& Matsui, Y. (2012). Contribution of total productive maintenance to quality performance: Empirical evidence from Japanese manufacturing plants. The Journal of Japanese Operations Management and Strategy, 3(1), 38-54.

Sureshchandar, G. S., Rajendran, C., \& Anantharaman, R. N. (2002). Determinants of customer-perceived service quality: A confirmatory factor analysis approach. Journal of Services Marketing, 16(1), 9-34. http://dx.doi.org/10.1108/08876040210419398

Thornton, G. (2012). Report Overview-Vietnam Hotel Survey 2012. Grant Thornton Vietnam.

Tsang, N., \& Qu, H. (2000). Service quality in China's hotel industry: A perspective from tourists and hotel managers. International Journal of Contemporary Hospitality Management, 12(5), 316-326. http://dx.doi. org $/ 10.1108 / 09596110010339706$

Türkyilmaz, A., \& Özkan, C. (2007). Development of a customer satisfaction index model: An application to the Turkish mobile phone sector. Industrial Management \& Data Systems, 107(5), 672-687. http://dx.doi.org/10. $1108 / 02635570710750426$

Vu, V. D. (2012). Khảo sát các nhân tố ảnh hưởng đến sự hài lòng của khách khi đến du lịch ở Bà Rịa- Vũng Tàu. Tạp chi phát triển và hội nhập, 16(6), 26-32.

Wilkins, H., Merrilees, B., \& Herington, C. (2007). Toward an understanding of total service quality in hotels. International Journal of Hospitality Management, 26(4), 840-853. http://dx.doi.org/10.1016/j.ijhm.2006. 07.006

\section{Copyrights}

Copyright for this article is retained by the author(s), with first publication rights granted to the journal.

This is an open-access article distributed under the terms and conditions of the Creative Commons Attribution license (http://creativecommons.org/licenses/by/3.0/). 